УДК 618.145-002.18:159.9

DOI 10.11603/24116-4944.2018.1.8743

๑А. В. Бойчук, В. С. Шадріна, Т. В. Верещагіна

ДВНЗ «Тернопільсъкий державний медичний університет імені І. Я. Горбачевсъкого МОЗ України»

\title{
ОЦІНКА ПСИХОСОМАТИЧНОГО СТАНУ В ЖІНОК ІЗ ГІПЕРПЛАСТИЧНИМИ ПРОЦЕСАМИ ЕНДОМЕТРІЯ
}

Мета дослідження - визначення особливостей особистості і темпераменту хворих із гіперпластичними процесами ендометрія до та після діагностичного вишкрібання стінок порожнини матки для виявлення дезадаптивних якостей особистості на основі запропонованої нами терапії.

Матеріали та методи. Обстежено 60 пацієнток із дисфрункціональними матковими кровотечами на фроні гіперпластичних процесів ендометрія. У всіх пацієнток визначали особливості особистості і характеру за опитувальником Клонінджера «Структура темпераменту і характеру». Дослідна група пацієнток отримувала запропоновану нами терапію: препарати, що містять діючу речовину - фенібут по 250 мг 2 рази на добу.

Результати дослідження та їх обговорення. До і після діагностичного вишкрібання стінок порожнини матки жінки, які отримували запропоновану нами терапію, легше справляються з ситуацією, яка склалася, порівняно 3 групою жінок, які отримували загальноприйняте лікування.

Висновок. Отримані дані вимагають обов'язкового врахування під час розроблення медико-психологічного супроводу в комплексній системі реабілітації жінок до і після діагностичного вишкрібання стінок порожнини матки 3 приводу гіперпластичних процесів ендометрія.

Ключові слова: гіперпластичні процеси ендометрія; психоемоційні розлади.

ОЦЕНКА ПСИХОСОМАТИЧЕСКОГО СОСТОЯНИЯ У ЖЕНЩИН С ГИПЕРПЛАСТИЧЕСКИМИ ПРОЦЕССАМИ ЭНДОМЕТРИЯ

Цель исследования - определение особенностей личности и характера больных с гиперпластическими процессами эндометрия до и после диагностического выскабливания стенок полости матки для выявления дезадаптивных качеств личности на основе предложенной нами терапии.

Материалы и методы. Обследовано 60 пациенток с дисфункциональными маточными кровотечениями на фроне гиперпластических процессов эндометрия. У всех пациенток определяли особенности личности и характера по опроснику Клонинджера «Структура темперамента и характера». Опытная группа пациенток получала предложенную нами терапию: препараты, содержащие действующее вещество - фенибут по 250 мг 2 раза в сутки.

Результаты исследования и их обсуждение. До и после диагностического выскабливания стенок полости матки женщины, получавшие предложенную нами терапию, легче справляются с сложившейся ситуацией, по сравнению с группой женщин, получавших общепринятое лечение.

Вывод. Полученные данные требуют обязательного учета при разработке медико-психологического сопровождения в комплексной системе реабилитации женщин до и после диагностического выскабливания стенок полости матки по поводу гиперпластических процессов эндометрия.

Ключевые слова: гиперпластические процессы эндометрия; психоэмоциональные расстройства.

ESTIMATION OF PSYCHOSOMATIC STATUS IN WOMEN WITH HYPERPLASTIC PROCEDURES OF ENDOMETRIUM

The aim of the study - to determine the peculiarities of the personality and temperament of patients with hyperplastic endometrium processes before and after the diagnostic eruption of the walls of the uterine cavity, in order to detect the maladaptive qualities of the individual on the basis of the therapy proposed by us.

Materials and Methods. 60 patients with dysfunctional uterine bleeding on the background of hyperplastic processes of endometrium were examined. All patients defined the personality and character of the questionnaire Cloninger "Structure of temperament and character." The experimental group of patients received the therapy we proposed: drugs containing the active substance - phenibut $250 \mathrm{mg} 2$ times a day.

Results and Discussion. Before and after the diagnostic eruption of the walls of the uterine cavity of women who received the therapy we offered easier to cope with the situation that developed in comparison with the group of women who received the usual treatment.

Conclusion. The data obtained require compulsory consideration during the development of medical and psychological support in the comprehensive system of rehabilitation of women before and after the diagnostic eruption of the walls of the uterine cavity with the introduction of hyperplastic processes of endometrium.

Key words: hyperplastic processes of endometrium; psycho-emotional disorders.

ВСтУп. Зростання питомої ваги раку ендометрія серед злоякісних новоутворень жіночих статевих органів спонукає до вивчення особливостей перебігу гіперпластичних процесів ендометрія. Гіперпластичні процеси ендометрія займають значне місце в структурі гінекологічної захворюваності жінок репродуктивного віку і $є$ однією із частих причин госпіталізації жінок у гінекологічний стаціонар. 
Своєчасна діагностика й лікування даної патології $€$ однією з актуальних проблем сучасної гінекології. Висока частота рецидивів гіперпластичних процесів ендометрія, можливість їх злоякісної транссрормації вимагають удосконалювання методів діагностики даної патології, переосмислення накопиченого досвіду [3].

За даними літератури, при дослідженні матеріалу, отриманого при гістеректомії, більш ніж в 60,0 \% випадків при попередньому кюретажі діагноз було встановлено не повною мірою або не точно, тому втілення ендоскопічних технологій $€$ перспективним напрямком сучасної гінекології $[4,8]$.

Однак не можна забувати про те, що об'єктом лікувальної діяльності в гінекології $€$ статеві органи жінки, і цей зв'язок із процесом статевого життя ускладнює роботу гінеколога, переплітаючись із безліччю психологічних, соціальних та етичних проблем. Для більшості жінок матка - символ жіночності, сексуальної молодості і здоров'я $[1,5]$

У дослідженнях у жінок, які звернулись по допомогу, важливо контролювати консультаційну поведінку, що сама по собі пов'язана із психологічним стресом [7]. Виникає необхідність в обґрунтованому диференційованому підході до лікування хворих із цією патологією й у можливості оцінювання ефективності призначеної терапії.

МЕТА ДОСЛІДЖЕННЯ - вИзначення особливостей особистості і темпераменту хворих із гіперпластичними процесами ендометрія за опитувальником Клонінджера, до та після діагностичного вишкрібання стінок порожнини матки, для виявлення змін дезадаптивних якостей особистості на основі запропонованої нами терапії.

МАТЕРІАЛИ ТА МЕТОДИ. НамИ було компЛексно обстежено 60 пацієнток віком від 37 і до 54 років із дисфункціональними матковими кровотечами на фоні гіперпластичних процесів ендометрія. Жінки були розподілені на 2 групи залежно від використаної терапії: відсутності (I група - контрольна) і наявності (II група - дослідна) запропонованої нами терапії. Кожну групу розподілено на підгрупи залежно від методу дослідження:

I A - (15 жінок) діагностичне вишкрібання порожнини матки («сліпе») + загальноприйняті реабілітаційні заходи;

I Б - (15 жінок) діагностичне вишкрібання порожнини матки (за допомогою гістероскопа) + загальноприйняті реабілітаційні заходи;

II A - (15 жінок) діагностичне вишкрібання порожнини матки («сліпе»)+ запропонована нами терапія;
ІІ Б - (15 жінок) діагностичне вишкрібання порожнини матки (за допомогою гістероскопа) + запропонована нами терапія.

Обстеження пацієнток із диссунціональними матковими кровотечами з приводу гіперплазії ендометрія проводили до та після діагностичного вишкрібання порожнини матки.

3 метою поглибленого аналізу скарг жінок за період до і після діагностичного вишкрібання стінок порожнини матки у всіх пацієнток визначали особливості особистості і характеру хворих із гіперпластичними процесами ендометрія за опитувальником Клонінджера «Структура темпераменту і характеру» [6, 7]. Особливість тесту Клонінджера в реалізації дименсіонального (лат. Dimensio - вимір, розмір, розміреність) підходу.

Опитувальник являє собою список із 140 тверджень, які складаються 3 шести шкал, які діляться на кілька субшкал. У ньому виділяються три базових вимірювання характеру: «Пошук нового», «Уникнення небезпеки» і «Залежність від заохочення». А три шкали характеру «Самостійність», «Кооперативність» і «Самотрансцендентність» дають додаткову інформацію про адаптивність особистості.

Основними моментами запропонованої нами терапії були такі: 1. Переддіагностична підготовка - препарати, що містять діючу речовину - сренібут по 250 мг 2 рази на добу за 1-2 дні до діагностичного вишкрібання порожнини матки. 2. Після діагностичного вишкрібання порожнини матки - по 250 мг 2 рази на добу 3-5 днів.

РЕЗУЛЬТАТИ ДОСЛІДЖЕННЯ ТА ЇХ ОБГОВОРЕННЯ. Результати в жінок, які пройшли обстеження до діагностичного вишкрібання, представлені на графріку 1. Після отримання результатів за допомогою опитувальника Клонінджера маємо, що I А і I Б групи (жінки, які отримували загальноприйняте лікування) характеризуються як завбачливі, тривожно-турботливі, невпевнені у собі, боязкі.

Інтерпретація даних II групи асоціюється 3 низьким рівнем тривожності, безтурботністю, сміливістю і впевненістю в собі. Жінок об'єднує інтернальний локус контролю, особистісна зрілість - вони вважають себе відповідальними за свої установки і поведінку, здатні довіряти іншим людям.

Результати у жінок, які пройшли обстеження після діагностичного вишкрібання, представлені на графіку 2.

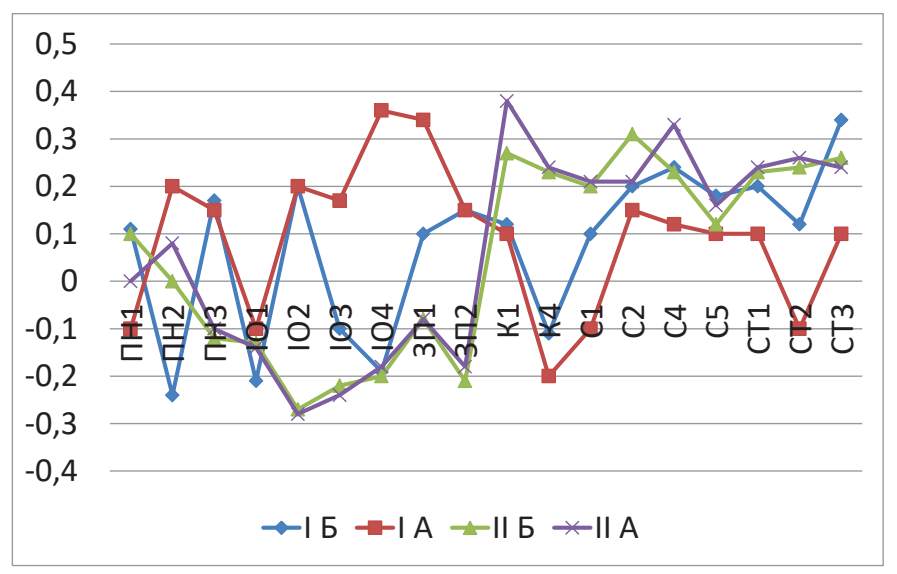

Грасрік 1. Особливості особистості та характеру перед діагностичним вишкрібанням порожнини матки («сліпе» та за допомогою гістероскопа). 


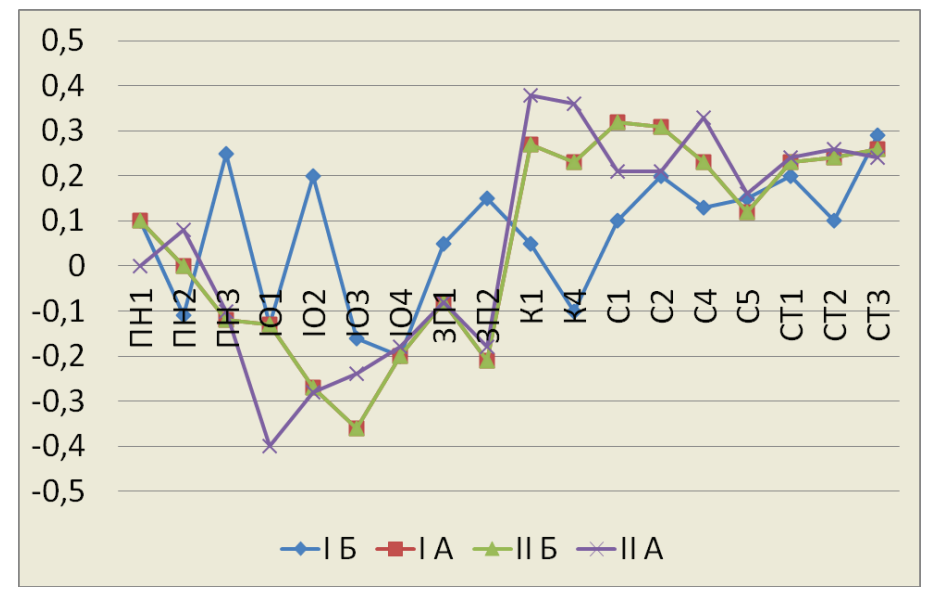

Грасрік 2. Особливості особистості та характеру після діагностичного вишкрібання («сліпе» та за допомогою гістероскопа).

Після обстеження рівень тривожності знизився для I і II груп. I групу жінок об'єднували такі характеристики, як втома, слабкість, незахищеність, невпевненість у собі. Для II групи об'єднані характеристики - це цілеспрямованість, конструктивність, зібраність, високий ступінь внутрішньої інтеграції «Я».

Разом з тим слід зазначити, що при високій достовірності результатів самі кореляції невеликі (від 0,11 до 0,19).

До і після діагностичного вишкрібання стінок порожнини матки II група жінок легше справляється з ситуацією, яка склалася (для них характерний прагматичний раціоналізм), порівняно з I групою жінок, яка вимагає більше часу, щоб «прийти до себе» після пережитого стресу.

ВИСНОВКИ. Психоемоційний стан жінок, які перенесли діагностичне вишкрібання стінок порожнини матки, відрізняється різноманітністю залежно від відсутності або наявності запропонованої нами терапії. Особливості особистості та характеру хворих із гіперпластичними процесами ендометрія за опитувальником Клонінджера, до і після діагностичного вишкрібання, характеризують жінок із запропонованою нами терапією (II група) більшою стійкістю порівняно з жінками, які пройшли загальноприйняті реабілітаційні заходи (І група). Запропонована нами терапія є есрективною для корекції психоемоційних станів у жінок із гіперпластичними процесами ендометрія. Отримані дані вимагають обов'язкового врахування під час розроблення медико-психологічного супроводу в комплексній системі реабілітації жінок до і після діагностичного вишкрібання стінок порожнини матки з приводу гіперпластичних процесів ендометрія.

ПЕРСПЕКТИВИ ПОДАЛЬШИХ ДОСЛІДЖЕНЬ. Перспективою подальших досліджень $є$ оцінка та покращення якості життя жінок із гіперпластичними процесами ендометрія.

\section{СПИСОК ЛІТЕРАТУРИ}

1. Бенюк В. О. Індивідуалізація лікування жінок репродуктивного та пременопаузального віку з гіперпластичними процесами ендометрія / В. О. Бенюк, В.М.Гончаренко // Здоровье женщины. - 2014. - № 10. - С. 125-129.

2. Оптимизация диагностики и лечения у больных с гиперплазией эндометрия в постменопаузе при сочетанной гинекологической патологии / С. Н. Буянова, Э. М. Гитинов, Н.В.Юдина, И. Д. Рижинашвили // Росс. вестн. акушера-гинеколога : науч.-практ. журн. - 2013. - T. 13, № 4. - C. 58-62.

3. Венгрова О. А. Роль гистероскопии в диагностике гиперплазии эндометрия / О. А. Венгрова // Актуал. питання фрармац. і мед. науки та практики : наук.-практ. журн. - 2013. - № 2 (Додаток). - С. 64.

4. Гиперплазия эндометрия - современный взгляд на проблему / П. Н. Веропотвелян, И. В. Гужевская, Н. П. Веропотвелян, Л. А. Жабицкая // Мед. аспекты здоровья женщины. - 2013. - № 10. - С. 33-40.

5. Карелина А. А. Психологические тесты / А. А. Карелина // ВЛАДОС. - 2003. - № 1. - С. 214-248.

6. Гиперпластические процессы эндометрия: вопросы патогенетической терапии / А. Л. Унанян, И. С. Сидорова, Д. В. Бабурин, Ю. М. Коссович // Гинекология : журн. для практ. врачей. - 2013. - Т. 15, № 5. - С. 32-35.

7. Райгородский Д. Я. Практическая психодиагностика / Д. Я. Райгородский // Методики и тесты. Издательство Бахpax. - 2006. - № 1. - С. 652-678.

8. Kicik T. Chromohysteroscopy for evaluation of endometrium in recurrent in vitro fertilization failure / T. Kucik, M. Safari // J. Assist Reprod. Genet. - 2008. - No. 25. - P. 79-82. 


\section{REFERENCES}

1. Beniuk, V.O., \& Honcharenko, V.M. (2014). Indyvidualizatsiia likuvannia zhinok reproduktyvnoho ta premenopauzalnoho viku z hiperplastychnymy protsesamy endometriia [Individualization of treatment of women of reproductive and premenopausal age with hyperplastic processes of endometrium]. Zdorovye zhenshchiny: vseukrainskiy nauchno-prakticheskiy zhurnal - Women's Health an All-Ukrainian Scientific and Practical Journal, (10), 125-129 [in Ukrainian].

2. Buyanova, S.N. (2013). Optymizatsiya diagnostiki i lecheniya u bolnykh s giperplaziyey endometriya $v$ postmenopauze pri sochetannoy ginekologicheskoy patologi [Optimization of diagnosis and treatment in patients with endometrial hyperplasia in postmenopause with combined gynecological pathology]. Rossyyskiy vestnik akusheraginekologa: Nauchno-prakticheskiy zhurnal - Russian Journal of Obstetrician-Gynecologist: Scientific and Practical Journal, 13 (4), 58-62 [in Russian].

3. Vengrova, O.A. (2013). Rol gisteroskopii v diagnostike giperplazii endometriya [The role of hysteroscopy in the diagnosis of endometrial hyperplasia]. Aktualni pytannia farmatsii $i$ medychnoi nauky ta praktyky: naukovo-praktychnyi zhurnal-Ac- tual Questions of Pharmacy and Medical Science and Practice: Scientific and Practical Journal, (2), 64 [in Russian].

4. Veropotvelyan, P.N., Guzhevskaya, I.V., Veropotvelyan, N.P., Zhabitskaya, L.A. (2013). Giperplaziya endometriya sovremennyy vzglyad na problemu [Hyperplasia of the endometrium - a modern view of the problem]. Meditsinskie aspekty zdorovya zhenshchiny - Medical Aspects of Women's Health, 10 (74), 33-40 [in Russian].

5. Karelina, A.A. (2003). Psikhologicheskie testy [Psychological tests]. VLADOS, (1), 214-248 [in Russian].

6. Unanyan, A.L. (2013). Giperplastichiskie protsessy endometriya: voprosy patogeneticheskoy terapii [Hyperplastic processes of endometrium: questions of pathogenetic therapy]. Ginekologiya: zhurnal dlya praktich. vrachey - Gynecology: A Journal for Practicing Doctors, 15 (5), 32-35 [in Russian].

7. Raygorodskiy, D.Ya. Prakticheskaya psikhodiagnostika [Practical psychodiagnostics]. Metodiky i testy. Izdatelstvo Bakhrakh - Methods and Tests - Publishing House Bakhrakh, (1), 652-678 [in Russian].

8. Kicik, T., \& Safari, M. (2008). Chromohysteroscopy for evaluation of endometrium in recurrent in vitro fertilization failure. J. Assist. Reprod. Genet., (25), 79-82. 